\title{
Mast Cell Inhibition Attenuates Cardiac Remodeling and Diastolic Dysfunction in Middle-aged, Ovariectomized Fischer344×Brown Norway Rats
}

\author{
Hao Wang, MD, PhD ${ }^{*}, \dagger$, Jaqueline da Silva, $\mathrm{PhD}^{*}, \neq$, Allan Alencar, $\mathrm{MS}^{*}, \ddagger$, Gisele Zapata- \\ Sudo, $\mathrm{PhD}^{\star}, \neq$, Marina S. Lin, MS ${ }^{\star}$, Xuming Sun, MD, PhD*, Sarfaraz Ahmad, PhD§, Carlos M. \\ Ferrario, MD $\$, \|$, and Leanne Groban, $\mathbf{M D}^{\star}, \dagger, \#, \uparrow$ \\ "Department of Anesthesiology, Wake Forest School of Medicine, Winston-Salem, NC, USA \\ tDepartment of Internal Medicine, Section on Molecular Medicine, Wake Forest School of \\ Medicine, Winston-Salem, NC, USA \\ ‡Division of Biomedical Sciences, Drug Development Program, Federal University of Rio de \\ Janeiro, Brazil \\ $\S$ Department of Surgery, Wake Forest School of Medicine, Winston-Salem, NC, USA \\ "Department of Internal Medicine, Section on Nephrology, Wake Forest School of Medicine, \\ Winston-Salem, NC, USA \\ \#Hypertension and Vascular Research Center, Wake Forest School of Medicine, Winston-Salem, \\ NC, USA \\ ISticht Center on Aging, Wake Forest School of Medicine, Winston-Salem, NC, USA
}

\section{Abstract}

The incidence of left ventricular diastolic dysfunction (LVDD) increases in women following menopause, yet the mechanisms are unclear. Because mast cells participate in the pathological processes of various cardiac diseases, we hypothesized that mast cell inhibition would protect against estrogen loss-induced LVDD. The mast cell stabilizer, cromolyn sodium (30 mg/kg/day), or vehicle was administered subcutaneously by osmotic minipump to ovariectomized (OVX) female Fischer344×Brown Norway (F344BN) rats starting at four weeks after surgery. Eight weeks after OVX, systolic blood pressure increased by $20 \%$ in OVX vs. sham rats, and this effect was attenuated after four weeks of cromolyn treatment. Also, cromolyn mitigated the adverse reductions in myocardial relaxation ( $\left.\mathrm{e}^{\prime}\right)$ and increases in left ventricle (LV) filling pressures (E/e'), LV mass, wall thicknesses, and interstitial fibrosis from OVX. While cardiac mast cell number was increased after OVX, cardiac chymase activity was not overtly altered by estrogen status and tended to decrease by cromolyn. Contrariwise, Ang II content was greater in hearts of OVX vs. sham rats, and cromolyn attenuated this effect. Taken together, mast cell inhibition with cromolyn

Address correspondence to: Leanne Groban, MD, Department of Anesthesiology, Wake Forest School of Medicine, Medical Center Boulevard, Winston-Salem, NC 27157-1009, Ph:336-716-4498 Fax: 336-716-8190 lgroban@ wakehealth.edu.

Conflict of interest statement: The authors declare no conflicts of interest in preparing this article. 
attenuates LV remodeling and LVDD in OVX-F344BN rats possibly through actions on the heart level and/or via vasodilatory effects at the vascular level.

\section{Keywords}

estrogen; menopause; chymase; angiotensin II; left ventricular remodeling

\section{Introduction}

Clinical studies in the general population show that approximately half of all heart failure (HF) patients have preserved ejection fraction. ${ }^{1,2}$ The increased heart failure with preserved ejection fraction (HFpEF) prevalence that has increased over the past three decades is a reflection, in part, of the growth of the aged population. Also, women are approximately two times more likely than men to develop heart failure in the setting of $\mathrm{HFpEF}^{3,4}$ In contrast to heart failure with reduced ejection fraction (HFrEF), there are no proven effective pharmacotherapies for HFpEF. ${ }^{1,2,5}$ Understanding the mechanisms underlying HFpEF in older women is critical for the development of effective interventions to limit and treat this healthcare problem.

Left ventricle diastolic dysfunction (LVDD), a precursor of HFpEF, is characterized by the abnormalities in left ventricular (LV) filling or relaxation that are present even in the absence of signs and symptoms of HF. ${ }^{6}$ One in six patients with asymptomatic LVDD is expected to develop overt HF symptoms within 5 years of diagnosis. ${ }^{7}$ Like HFpEF, LVDD is seen in both men and women, but it is more prevalent in postmenopausal women, suggesting a link between LVDD and estrogen deficiency. ${ }^{8}$ This possibility gained support from a previous study from this laboratory that showed estrogen loss by ovariectomy (OVX) in mRen2.Lewis rats induced heart remodeling and LVDD, which were attenuated by chronic treatment with $17 \beta$-estradiol (E2) or G1, a specific agonist to the new membrane estrogen receptor, GPER. ${ }^{9}, 10$ Further study revealed that OVX-induced LVDD is associated with increases in cardiac mast cell number, chymase expression, and cardiac tissue angiotensin II (Ang II) levels. ${ }^{11}$ Indeed, mast cells are a source of chymase, which can generate Ang II from Ang-I or Ang-1-12, ${ }^{12}$ and a wide variety of cytokines, vasoactive agents, and inflammatory factors. Previous studies using animal models of pressure or volume-overload suggest that cardiac mast cells have an important role in the development of cardiac hypertrophy and HF through various pathways including chymase/Ang II, chymase/matrix metalloproteinase (MMP) and cardiac inflammation. ${ }^{13-16}$ However, the contribution of cardiac mast cells to the development of LVDD after estrogen loss in a model of normative aging is not clear.

Translational research of postmenopausal LVDD suffers from a lack of suitable rodent models to define the mechanisms responsible for female-sex specific LVDD in the context of aging. The hybrid Fischer344×Brown Norway (F344BN) rat is considered to be an ideal model for the study of normal mammalian cardiac aging because its cardiovascular phenotype is not confounded by concomitant obesity and renal dysfunction. ${ }^{17}$ Although there are no reports using these rats to study the impact of estrogen loss on LVDD, 
Pechenino and colleagues ${ }^{18}$ found that OVX in middle-aged female F344BN rats significantly increased cardiac extracellular matrix-related and inflammatory gene expression. These data support the potential of aged, OVX F344BN rats as a model for studying the effects of estrogen loss and age on cardiac remodeling, LV hypertrophy, and LVDD.

In this study, we tested the hypothesis that mast cell inhibition by the mast cell stabilizer cromolyn sodium attenuates the adverse effects of estrogen loss on the development of LVDD in a rodent model of normal aging. We also investigated whether the cardioprotective effects of mast cell inhibition were related to reductions in cardiac chymase-mediated Ang II production after estrogen loss. We studied the effect of OVX of F344BN rats at middle-age (18 months) on systolic blood pressure (SBP), myocardial relaxation, and filling pressures 8weeks post-estrogen loss when compared to age-matched, sham-operated F344BN rats.

\section{Methods}

\section{Animals}

17-month-old female F344BN rats were purchased from the National Institute on Aging colony at Harlan Industries (Indianapolis, IN, USA) and were studied after 1 month of acclimation to their housing conditions. Rats were housed two per cage and were maintained on a 12-hour light/dark cycle, at constant temperature and humidity, in a facility approved by the Association for Assessment and Accreditation of Laboratory Animal Care. Rats had ad libitum access to standard rat chow (Nestle Purina, St. Louis, MO) and tap water. All procedures were in compliance with the Guide for the Care and Use of Laboratory Animals, published by the National Institutes of Health, and were reviewed and approved by the Wake Forest School of Medicine's Animal Care and Use Committee before commencement of the study (Approved protocol \#A12-201).

\section{Experimental protocol}

At 18 months of age, rats underwent either bilateral OVX $(n=14)$ or a sham procedure $(n=$ 7) under anesthesia by inhalation of $2 \%$ isoflurane and an air/oxygen mixture, as described previously. ${ }^{9,10}$ The adequacy of anesthesia was monitored by the observation of slow breathing, loss of muscular tone, and a lack of response to surgical manipulation. The success of OVX and subsequent depletion of circulating estrogens were confirmed using a serum estradiol assay (Polymedco, Cortlandt Manor, NY, USA) at the completion of the study protocol. Once the rats reached 19 months of age, the OVX group was randomized to receive either subcutaneous cromolyn sodium (OVX-cromolyn, Sigma-Aldrich, St. Louis, MO, USA), diluted in normal saline for a targeted dose of $30 \mathrm{mg} / \mathrm{kg} /$ day, or vehicle (OVX-V, saline) ( $\mathrm{n}=7 /$ group) administered via implanted ALZET osmotic mini-pumps (DURECT Corporation, Cupertino, CA, USA). Weekly body weight and SBP by tail-cuff plethysmography (NIBP-LE5001, Panlab, Barcelona, Spain) were monitored throughout the study. After 4 weeks of treatment, rats underwent terminal echocardiographic evaluation while under ketamine/xylazine anesthesia and then were euthanized via exsanguination by cardiac puncture (ketamine $\mathrm{HCl} 60 \mathrm{mg} / \mathrm{kg}$ and xylazine $\mathrm{HCl} 5 \mathrm{mg} / \mathrm{kg}$ ). Whole hearts were removed and further dissected to isolate the left ventricle, right ventricle, and atria. The left 
ventricle was cut into pieces and used to prepare RNA for real-time quantitative RT-PCR (qPCR), chymase activity, or fixed in $4 \%$ paraformaldehyde and embedded into paraffin blocks for histological analyses.

\section{Echocardiographic evaluation}

Echocardiography of all animals was performed at the end of the treatment period using a Philips 5500 echocardiograph (Philips Medical Systems, Andover, MA, USA) and a 12MHz pediatric phased-array probe (s12 Philips; Philips Medical Systems) by an experienced echocardiographer (LG) who was blinded to the experimental groups. For the procedure, animals were anesthetized with an intramuscular injection of ketamine $\mathrm{HCl} 60 \mathrm{mg} / \mathrm{kg}$ and xylazine $\mathrm{HCl} 5 \mathrm{mg} / \mathrm{kg}$. Sedated, spontaneously breathing animals were placed in a shallow left lateral decubitus position with electrocardiographic adhesive electrodes applied to the paws. The left hemithorax was shaved and prepped with acoustic coupling gel to increase probe contact. Animals were secured to the surface of a warming table to maintain normothermia. Heart structure and function were assessed and calculated as previously reported. ${ }^{9}, 10$ Specifically, LV end-diastolic dimension (LVEDD), LV end-systolic dimension (LVESD), LV posterior wall thickness (PWT), and LV anterior wall thickness (AWT) at the end of diastole were measured from midpapillary short-axis images obtained by M-mode echocardiography. The percentage of LV fractional shortening (FS), an index of contractile function, was calculated as FS $(\%)=[($ LVEDD - LVESD $) / L V E D D] \times 100$. LV mass was calculated using a standard cube formula, which assumes a spherical LV geometry according to the formula: $\mathrm{LV}$ mass $=1.04 \times\left[(\mathrm{LVEDD}+\mathrm{PWT}+\mathrm{AWT})^{3}-\mathrm{LVEDD}\right]$, where 1.04 is the specific gravity of muscle. Relative wall thickness (RWT) was calculated as: $2 \times$ PWT / LVEDD. LV diastolic function was assessed using conventional and tissue Doppler imaging. From an apical four-chamber orientation, early transmitral filling velocity $\left(\mathrm{E}_{\max }\right)$, late transmitral filling velocity $\left(\mathrm{A}_{\max }\right)$, and early deceleration time $\left(\mathrm{E}_{\mathrm{dec}}\right)$ were obtained with the Doppler sample volume placed at the mitral valve leaflet tips. The ratio of early transmitral filling-to-late transmitral filling (E/A) was calculated. Early mitral annular velocity (e') and the ratio of early transmitral filling velocity-to-early mitral annular velocity (E/e') were obtained using pulsed tissue Doppler imaging. Myocardial performance index (MPI), which is the ratio of total time spent in isovolumic activity (isovolumic contraction time and isovolumic relaxation time) to the ejection time, was calculated as previously described. ${ }^{19}$ At least five consecutive cardiac cycles, on average, were used to minimize beat-to-beat variability for all measured and calculated systolic and diastolic indices.

\section{Collagen staining}

Paraformaldehyde-fixed and paraffin-embedded LV specimens were cut into $4 \mu \mathrm{m}$ sections and collagen was stained with picrosirius red, as previously described. ${ }^{9,10}$ Images were captured using an Axiovert 200 microscope (Thornwood, NY, USA). The ratio of collagenstained pixels to unstained pixels was quantified using NIH ImageJ software (http:// rsbweb.nih.gov/ij/).

\section{Immunohistochemical analysis}

Immunohistochemistry on formalin-fixed and paraffin-embedded LV sections was performed using standard procedures. Left ventricular sections were incubated with 
antibodies against Ang II (1:10000, IgG Corp, Nashville, TN, USA) or chymase (1:1000, Bioss, Woburn, MA, USA) overnight at $4^{\circ} \mathrm{C}$, rinsed with phosphate-buffered saline, and incubated with biotinylated secondary IgG (Vector Laboratories, Burlingame, CA, USA) for $3 \mathrm{~h}$ at $4{ }^{\circ} \mathrm{C}$. Antibody binding was detected with the Vectastain ABC Elite avidin/biotin/ peroxidase kit (Vector Laboratories). The tissue sections were observed under a Leica DM4000B microscope. Pictures were taken from 10 random fields, and NIH ImageJ software was used to quantify staining in the heart.

\section{Chymase activity analysis}

The chymase activity was analyzed by measuring the ${ }^{125}$ I-Angiotensin II (125I-Ang II) product formation from ${ }^{125}$ I-Angiotensin-(1-12) substrate $\left[{ }^{125} \mathrm{I}\right.$-Ang-(1-12)] using reversephase, high-performance liquid chromatography (HPLC) as we previously described. ${ }^{20,21}$ Briefly, 50-100 $\mu \mathrm{g}$ of LV native plasma membranes (PMs) were preincubated with or without chymase inhibitor (chymostatin, $50 \mu \mathrm{M}$ ) for $15 \mathrm{~min}$. Other inhibitors (lisinopril, SCH39373, MLN-4760, amastatin, bestatin, benzylsuccinate and p-chlomercuribenzoate, each $50 \mu \mathrm{M}$ ) were also added to inhibit the renin-angiotensin enzymes (ACE/ACE2/ neprilysin), peptidases and metalloprotease. After preincubation of PMs with inhibitor cocktail, $1 \mathrm{nmol} / \mathrm{L}$ of the ${ }^{125} \mathrm{I}$-Ang-(1-12) substrate was added to the reaction mixture and incubated for additional $30 \mathrm{~min}$ at $37^{\circ} \mathrm{C}$. The reaction was then stopped by $1 \%$ phosphoric acid and centrifuged at $28,000 \mathrm{~g}$ for $20 \mathrm{~min}$. The supernatants were filtered and ${ }^{125} \mathrm{I}$-Ang II products were separated by HPLC on C-18 column using a linear gradient from 10-50\% mobile phase $\mathrm{B}$ at a flow rate of $0.35 \mathrm{~mL} / \mathrm{min}$ at $32^{\circ} \mathrm{C}$. The eluted $125 \mathrm{I}$-Ang II product was monitored by an in-line flow-through gamma detector (BioScan Inc., Washington, DC). Products were identified by comparison of retention time of synthetic $\left[{ }^{125} \mathrm{I}\right]$ standard Ang peptides, and the data were analyzed with Shimadzu LCSolution (Kyoto, Japan) acquisition software. Chymase activity was normalized by protein concentration and enzyme activity was reported as fmoles of ${ }^{125} \mathrm{I}$-Ang II formation from parent substrate [ ${ }^{125} \mathrm{I}$-Ang-(1-12)] per min per $\mathrm{mg}$ protein (fmol/min/mg protein).

\section{Quantitative real-time RT-PCR (qPCR)}

qPCR was used to detect LV gene mRNA levels, as previously described. ${ }^{10}$ Total RNA was extracted from frozen, pulverized LV tissue using TRIzol Reagent (Qiagen Inc, Valencia, CA, USA). Complementary first strand DNA was synthesized using the Omniscript RT kit (Qiagen Inc). Relative quantification of mRNA levels by qPCR was performed using a SYBR Green PCR kit (Qiagen Inc). Amplification and detection were performed with the ABI7500 Sequence Detection System (Applied Biosystems). Sequence-specific oligonucleotide primers were designed according to published GenBank sequences and confirmed with OligoAnalyzer 3.0. The relative target mRNA levels in each sample were normalized to GAPDH. Expression levels are reported relative to the mean value of the control group.

\section{Statistical analysis}

All results are reported as mean \pm SEM. For all endpoints, one-way ANOVA was used to determine the significance of differences among groups. Significant interactions between groups were determined using Tukey post-hoc tests. Differences for all tests were considered 
significant at $P<0.05$. Analyses were performed using GraphPad Prism, version 6

(GraphPad, San Diego, CA, USA).

\section{Results}

\section{OVX decreases circulating estrogens and increases body weight}

Confirming the efficacy of surgical bilateral OVX, serum estradiol levels in OVX-rats (4.1 $\pm 0.9 \mathrm{pg} / \mathrm{ml})$, irrespective of cromolyn $(3.0 \pm 0.5 \mathrm{pg} / \mathrm{ml})$, were significantly reduced compared to sham-operated littermates $(18.7 \pm 6.4 \mathrm{pg} / \mathrm{ml})$. As expected, ${ }^{22}$ estrogen loss by OVX increased body weight in middle-aged F344BN rats. Interestingly, this body weight increase in OVX rats was inhibited by chronic cromolyn treatment; an effect that has not been previously reported (Table 1).

\section{OVX increases and cromolyn restores blood pressure}

Consistent with our previous studies using young mRen2.Lewis rats, ${ }^{9,10}$ loss of ovarian estrogens increased blood pressure in middle-aged F344BN rats. Seven weeks after OVX, SBP was $141 \pm 6 \mathrm{mmHg}$ in OVX rats vs. $108 \pm 4 \mathrm{mmHg}$ in sham-operated littermates $(P<0.01)$. Serial blood pressure measurements during the 4-week treatment period showed that chronic cromolyn treatment limited OVX-related increases in blood pressure, as levels in OVX-cromolyn rats were not different from their sham vehicle-treated counterparts (Fig. 1) two weeks after initiation of the treatment.

\section{Cromolyn attenuates the adverse effects of estrogen loss on diastolic function}

Although overt differences in the early-to-late (E/A) transmitral Doppler filling ratios were not observed among groups, the 4-week subcutaneous infusion of cromolyn inhibited the decrease in myocardial relaxation ( $\left.\mathrm{e}^{\prime}\right)$, and the increase in Doppler-derived LV filling pressures $\left(E / e^{\prime}\right.$ ) that occurred following the surgical loss of estrogens in this strain (Fig. 2A and B). Systolic function, as determined by percent fractional shortening, was not affected by the loss of estrogens or the administration of cromolyn (Table 1).

\section{Cromolyn attenuates the effect of estrogen loss on cardiac fibrosis and remodeling}

While the surgical loss of estrogens at middle-age in F344BN rats did not change whole heart and LV-corrected weights (Table 1), echocardiographic measures of LV mass and relative wall thickness were increased $31 \%$ and $39 \%$ in OVX-rats, respectively, when compared to their sham-operated counterparts $(P<0.01)$. More importantly, the increases in LV mass and relative wall thickness in OVX rats were attenuated by chronic cromolyn treatment (Table 1).

Consistent with our previous findings in mRen2.Lewis rats,,${ }^{9,10}$ collagen deposition as a marker of interstitial fibrosis was modestly but significantly enhanced in LV sections of OVX-F344BN rats when compared to sham-operated littermates (OVX: $8.8 \pm 1.0 \%$ vs. Sham: $6.3 \pm 0.4 \%, P<0.05)$. This increase in collagen was attenuated by cromolyn treatment (OVX-cromolyn: $6.7 \pm 0.3 \%$ vs. OVX-V: $8.8 \pm 1.0 \%, P<0.05$ ) (Fig. 3A-B). Real-time qPCR revealed that in the LVs from OVX rats, collagen 1a1 mRNA level was increased $68 \%$ when compared with hearts from sham-operated rats, and this effect was attenuated by cromolyn 
treatment. Collagen $1 \mathrm{a} 2$ and collagen $3 a 1$ mRNA levels were not different among groups (Fig. 3C).

\section{OVX increases LV mast cell number in F344BN rats}

Immunohistochemical staining with an antibody specifically directed against chymase was used to identify mast cells in the $\mathrm{LV}$, as we described previously. ${ }^{11}$ Mast cell number in OVX rats was significantly higher compared to sham-operated controls $(P<0.05)$ and, as expected, chronic treatment with the mast cell stabilizer did not alter their number after OVX (Fig. 4).

\section{Effects of OVX and cromolyn on cardiac chymase activity and Ang II content}

Mast cells are the main source of chymase, which among other functions is a primary Ang II forming enzyme in both rodents and human tissues. ${ }^{23}$ Our previous study showed that cardiac mast cell/chymase/Ang II axis was associated with the development of LVDD after estrogen loss by OVX in the mRen2.Lewis congenic strain. ${ }^{11}$ However, in the present study, cardiac chymase activity was not overtly influenced by estrogen status or cromolyn $(P=0.06$, Fig. 5A), but Ang II content in LVs of OVX rats increased when compared with shamoperated rats, which was attenuated by cromolyn treatment (Fig. 5B). Correlation analysis showed a positive relationship between cardiac chymase activity and Ang II content $(P<0.05$, Fig. 5C).

\section{Discussion}

This study demonstrated that OVX-induced increases in cardiac fibrosis and LVDD in F344BN rats at middle-age, might occur partly through a mast cell-mediated pathway at the heart level and/or via vasodilatory effects at the vascular level. ${ }^{24-26}$

Cromolyn, which is characterized as a "mast cell stabilizer" by inhibiting mast cell degranulation, has been widely used in animal models to investigate the biological roles of mast cells. ${ }^{16,27-29}$ In the present study, cromolyn reversed the blood pressure elevation, cardiac collagen deposition, and LVDD induced by the removal of the ovaries. While cromolyn therapy did not affect cardiac mast cell number, it was associated with a decrease in cardiac Ang II content. Given that local cardiac chymase activity was unchanged by OVX or cromolyn, we cannot exclude the possibility that systemic mast cell-secreted chymase was affected and, in turn, regulated cardiac Ang II content; mast cells are found in most tissues in the body, particularly connective tissue.

\section{Animal models for female-sex specific LVDD or HFpEF}

Heart failure with preserved ejection fraction and LVDD is a growing public health issue, yet there is no established therapy and recent studies have not demonstrated significant benefits of new treatments under investigation. ${ }^{1,2,5}$ Various animal models have been used in the study of LVDD, including the mRen2.Lewis rats, ${ }^{9,10}$ deoxycorticosterone acetatehypertensive rats, ${ }^{30}$ spontaneously hypertensive rats (SHR), ${ }^{31}$ streptozotocin and a high-fat diet-induced diabetic rats and mice, ${ }^{32,33}$ lipopolysaccharide-induced high inflammation and LVDD, ${ }^{34}$ and aortocaval fistula-induced volume overload model. ${ }^{35}$ However, all these 
animal models are pathological models and may not reflect the biological conditions of LVDD that exist in healthy, aging women after the cessation of ovarian estrogen production.

The hybrid F344BN rat is recommended for age-related studies by the National Institutes on Aging because it lives longer and has a lower incidence of age-related pathology than other rat strains; its cardiovascular phenotype during aging is not confounded by concomitant obesity, renal dysfunction, and other pathological conditions. ${ }^{17}$ To our knowledge, no studies using the F344BN rat strain have investigated the effects of estrogen loss on the development of LVDD. We show that OVX at middle-age in F344BN rats led to hypertension, cardiac fibrosis, and LVDD when compared to their sham-operated, agematched counterparts suggesting that in addition to its touted uses for the study of cardiac aging, this model might also be suitable for the study of estrogens effects in the maintenance of cardiac structure and function in females.

The commonly used echocardiographic measurements for diastolic function include the conventional Doppler-derived early-to-late transmitral filling ratio (E/A), and the tissue Doppler-derived early mitral annular velocity $\left(\mathrm{e}^{\prime}\right)$ and transmitral early filling-to-mitral annular velocity ratio, or E/e' ${ }^{36,37}$ In this study, although overt differences in E/A were not observed among groups, cromolyn treatment prevented the decrease in $\mathrm{e}^{\prime}$, and the increase in E/e' that occurred following the surgical loss of estrogens in this strain. Indeed, E/A ratio is preload and heart rate dependent, and can be "pseudonormal" during the development of LVDD. ${ }^{38,39}$ In contrast, $\mathrm{e}^{\prime}$ and E/e' are less load and heart rate dependent and are deemed to be more reliable measures of diastolic function than conventional Doppler, particularly since mitral annular velocities decline with worsening LVDD whereas E/A ratios show a parabolic pattern with worsening of diastolic function. ${ }^{40,41}$ Moreover, E/e' is more sensitive than E/A for the detection of LVDD in patients with systemic sclerosis or systemic lupus erythematosus. ${ }^{42,43}$

\section{Estrogen, mast cells, and blood pressure}

In addition to inducing structural evidence of LVDD, estrogen loss by OVX increased SBP in F344BN rats, reflecting another characteristic of older women after the menopause. The cessation of ovarian estrogen production appears to contribute to hypertension in older women. ${ }^{44,45}$ The mechanism as to how estrogen loss increases blood pressure is still unclear, but studies implicate activation of the circulating and tissue renin-angiotensin system, endothelin, and inflammatory processes. ${ }^{46,47}$ Interestingly, in the present study, the OVXinduced blood pressure increase was inhibited by chronic mast cell inhibition, suggesting mast cell activation might mediate the blood pressure increase in middle-aged OVXF344BN rats. Findings from mast cell-deficient mice show that mast cells and mast cellmediated production of Ang II might be involved in blood pressure regulation. ${ }^{26}$ However, the influence of mast cell/chymase/Ang II on blood pressure may differ among animal models, as in SHRs, acute treatment with a chymase inhibitor did not change blood pressure. ${ }^{48}$ In addition to chymase/Ang II, mast cells are a source of a wide variety of cytokines, vasoactive agents, and inflammatory factors, all of which might affect blood pressure. Since chymase stimulates the expression of MMPs, the finding of reduced collagen type $1 \mathrm{~A}$ content following exposure to cromolyn agrees with the possibility that at least part 
of the beneficial effects of this mast cell stabilizer drug may be accounted for by chymase inhibition, despite only a tendency in reduced cardiac chymase activity following cromolyn.

\section{Cardiac mast cells in LV remodeling and heart failure}

Mast cells appear to be potent mediators of adverse myocardial remodeling and HF. Increased mast cell number has been reported in explanted human hearts with dilated cardiomyopathy and in animal models of chronic cardiac volume overload, pressure overload, myocardial infarction, and spontaneous hypertension. ${ }^{13-16}$ Also, in mast celldeficient animals or when mast cell degranulation is pharmacologically prevented, studies show that cardiac remodeling and HF can be considerably attenuated. ${ }^{16,49-51}$

Correspondingly, in the SHR model, inhibition of mast cell function prevented the development of fibrosis. ${ }^{52}$ Consistent with these previously reported maladaptive effects of mast cell activation, we showed in the F344BN rat that cromolyn is capable of limiting extracellular matrix remodeling and LVDD which occurred following estrogen loss at middle-age, either indirectly by preventing OVX-related increases in blood pressure ${ }^{23,24}$ or via direct effects on the heart. The precise cardioprotective mechanisms of cromolyn remain to be fully characterized since the mast cell stabilizer cromolyn has been reported to inhibit the release of preformed inflammatory cytokines from T-cells and eosinophils, ${ }^{53}$ as well as act as a weak inhibitor of calcium channels..$^{54}$

\section{Estrogen and cardiac mast cells}

The inverse association between estrogen status and cardiac mast cell number observed in the middle-aged, healthy aging F344BN rat is consistent with reports using female rats with diseased hearts from induced hypertension or pressure or volume overload. Our previous study in the hypertensive mRen2.Lewis rat showed that estrogen loss by OVX increased cardiac mast cell number and that treatment with $17 \beta$-estradiol limited this effect. ${ }^{11} \mathrm{Li}$ et al. ${ }^{15}$ recently reported that aortic constriction in female rats resulted in an increase in cardiac mast cell density in OVX rats, but not in estrogen-intact rats. Moreover, estrogen replacement markedly attenuated this pressure overload-mediated increase in mast cell density. Similarly, in volume-overload rats, a greater mast cell density was noted in male and OVX females, but not in ovary-intact females. ${ }^{55}$ Indeed, estrogen has been shown to regulate mast cell number in vivo in other tissues and species. ${ }^{56-59}$ The mechanisms by which estrogen regulates mast cell differentiation, proliferation, maturity, and subsequently mast cell number remain unclear. However, recent in vitro findings from our laboratory provide evidence that estrogen inhibits RBL-2H3 mast cell proliferation, in part by a G-proteincoupled estrogen receptor/cyclin-dependent kinase 1 (CDK1) pathway. ${ }^{8}$ Thus, it appears that in the F344BN rat, estrogen loss might directly induce an increase in cardiac mast cell number by promoting cell proliferation or stimulating the maturation of resident immature mast cells, rather than by other compensatory mechanisms.

\section{Limitations and future studies}

As described by other groups, ${ }^{16,27-29}$ chronic subcutaneous administration of the mast cell stabilizer, cromolyn, was used in this study to investigate the potential role of mast cells in the pathogenesis of LVDD following the loss of ovarian estrogens. Since mast cells are 
found in most tissues in the body, the systemic administration of cromolyn could have had direct effects on other cardiovascular tissue besides the heart. We cannot rule out the beneficial effects of cromolyn on limiting the OVX-related increase in blood pressure and peripheral vascular inflammatory responses ${ }^{60,61}$ in F344BN rats and, in turn, attenuating diastolic dysfunction and LV remodeling following estrogen deficiency in this model. Indeed, even modest blood-pressure-lowering actions can benefit diastolic function. ${ }^{62,63}$

Moreover, besides chymase, the systemic administration of cromolyn could have direct effects on the release of vasoactive agents, cytokines, and inflammatory factors including IL-6, IL-1, IFN $\gamma$, TNFa, histamine, prostaglandins, and platelet-activating factor (PAF) from mast cells, all of which are involved in diseases of the cardiovascular system. ${ }^{64}$ Besides chymase/Ang II, it will be important to study whether other mast-cell-derived factors contribute to the progression of cardiac aging and diastolic dysfunction after estrogen loss.

\section{Conclusions}

In summary, this study demonstrated that the OVX-F344BN rat is a suitable animal model for the study of LVDD that is common in postmenopausal women. Mast cell inhibition by the mast cell stabilizer, cromolyn, attenuated the adverse effects of estrogen loss on cardiac remodeling and diastolic function. Even though it is not clear how estrogen might regulate cardiac mast cell/Ang II and/or how mast cell-released factors might influence diastolic function, this study provides the impetus for future research focusing on the cardioprotective potential of cardiac mast cell antagonism in the development and progression of LVDD after estrogen loss.

\section{Acknowledgments}

Funding: This research was supported by grants AG042758 and AG033727 (LG) from the National Institute on Aging (NIA) of National Institutes of Health and grant HL-051952 from the National Heart Lung and Blood Institute (NHLBI), National Institutes of Health (CMF).

\section{References}

1. Upadhya B, Taffet GE, Cheng CP, Kitzman DW. Heart failure with preserved ejection fraction in the elderly: scope of the problem. J Mol Cell Cardiol. 2015; 83:73-87. [PubMed: 25754674]

2. Borlaug BA. The pathophysiology of heart failure with preserved ejection fraction. Nat Rev Cardiol. 2014; 11:507-15. [PubMed: 24958077]

3. den Ruijter H, Pasterkamp G, Rutten FH, Lam CS, Chi C, Tan KH, van Zonneveld AJ, Spaanderman M, de Kleijn DP. Heart failure with preserved ejection fraction in women: the Dutch Queen of Hearts program. Neth Heart J. 2015; 23:89-93. [PubMed: 25614387]

4. Scantlebury DC, Borlaug BA. Why are women more likely than men to develop heart failure with preserved ejection fraction? Curr Opin Cardiol. 2011; 26:562-8. [PubMed: 21993357]

5. Asrar ul Haq M, Wong C, Mutha V, Anavekar N, Lim K, Barlis P, Hare DL. Therapeutic interventions for heart failure with preserved ejection fraction: A summary of current evidence. World J Cardiol. 2014; 6:67-76. [PubMed: 24575173]

6. Lam CS, Lyass A, Kraigher-Krainer E, Massaro JM, Lee DS, Ho JE, Levy D, Redfield MM, Pieske BM, Benjamin EJ, Vasan RS. Cardiac dysfunction and noncardiac dysfunction as precursors of heart failure with reduced and preserved ejection fraction in the community. Circulation. 2011; 124:24-30. [PubMed: 21670229] 
7. Aurigemma GP, Gaasch WH. Clinical practice. Diastolic heart failure. N Engl J Med. 2004; 351:1097-105. [PubMed: 15356307]

8. Zhao Z, Wang H, Jessup JA, Lindsey SH, Chappell MC, Groban L. Role of estrogen in diastolic dysfunction. Am J Physiol Heart Circ Physiol. 2014; 306:H628-40. [PubMed: 24414072]

9. Jessup JA, Wang H, MacNamara LM, Presley TD, Kim-Shapiro DB, Zhang L, Chen AF, Groban L. Estrogen therapy, independent of timing, improves cardiac structure and function in oophorectomized mRen2.Lewis rats. Menopause. 2013; 20:860-8. [PubMed: 23481117]

10. Wang H, Jessup JA, Lin MS, Chagas C, Lindsey SH, Groban L. Activation of GPR30 attenuates diastolic dysfunction and left ventricle remodelling in oophorectomized mRen2.Lewis rats. Cardiovasc Res. 2012; 94:96-104. [PubMed: 22328091]

11. Wang H, Jessup JA, Zhao Z, Da Silva J, Lin M, MacNamara LM, Ahmad S, Chappell MC, Ferrario CM, Groban L. Characterization of the cardiac renin angiotensin system in oophorectomized and estrogen-replete mRen2.Lewis rats. PLoS One. 2013; 8:e76992. [PubMed: 24204720]

12. Ferrario CM, Ahmad S, Nagata S, Simington SW, Varagic J, Kon N, Dell'italia LJ. An evolving story of angiotensin-II-forming pathways in rodents and humans. Clin Sci (Lond). 2014; 126:4619. [PubMed: 24329563]

13. Stewart JA Jr, Wei CC, Brower GL, Rynders PE, Hankes GH, Dillon AR, Lucchesi PA, Janicki JS, Dell'Italia LJ. Cardiac mast cell- and chymase-mediated matrix metalloproteinase activity and left ventricular remodeling in mitral regurgitation in the dog. J Mol Cell Cardiol. 2003; 35:311-9. [PubMed: 12676546]

14. Levick SP, Meléndez GC, Plante E, McLarty JL, Brower GL, Janicki JS. Cardiac mast cells: the centrepiece in adverse myocardial remodelling. Cardiovasc Res. 2011; 89:12-9. [PubMed: 20736239]

15. Li J, Jubair S, Janicki JS. Estrogen inhibits mast cell chymase release to prevent pressure overloadinduced adverse cardiac remodeling. Hypertension. 2015; 65:328-34. [PubMed: 25403608]

16. Brower GL, Chancey AL, Thanigaraj S, Matsubara BB, Janicki JS. Cause and effect relationship between myocardial mast cell number and matrix metalloproteinase activity. Am J Physiol Heart Circ Physiol. 2002; 283:H518-25. [PubMed: 12124196]

17. Lipman RD, Chrisp CE, Hazzard DG, Bronson RT. Pathologic characterization of brown Norway, brown Norway x Fischer 344, and Fischer 344 x brown Norway rats with relation to age. J Gerontol A Biol Sci Med Sci. 1996; 51:B54-9. [PubMed: 8548501]

18. Pechenino AS, Lin L, Mbai FN, Lee AR, He XM, Stallone JN, Knowlton AA. Impact of aging vs. estrogen loss on cardiac gene expression: estrogen replacement and inflammation. Physiol Genomics. 2011; 43:1065-73. [PubMed: 21750230]

19. Sirvente RA, Irigoyen MC, Souza LE, Mostarda C, La Fuente RN, Candido GO, Souza PR, Medeiros A, Mady C, Salemi VM. Cardiac impairment evaluated by transesophageal echocardiography and invasive measurements in rats undergoing sinoaortic denervation. PLoS One. 2014; 9:e87935. [PubMed: 24828834]

20. Ahmad S, Wei CC, Tallaj J, Dell'Italia LJ, Moniwa N, Varagic J, Ferrario CM. Chymase mediates angiotensin-(1-12) metabolism in normal human hearts. J Am Soc Hypertens. 2013; 7:128-36. [PubMed: 23312967]

21. Nagata S, Varagic J, Kon ND, Wang H, Groban L, Simington SW, Ahmad S, Dell'Italia LJ, VonCannon JL, Deal D, Ferrario CM. Differential expression of the angiotensin-(1-12)/chymase axis in human atrial tissue. Ther Adv Cardiovasc Dis. 2015; 9:168-80. [PubMed: 26082339]

22. Chen Y, Heiman ML. Increased weight gain after ovariectomy is not a consequence of leptin resistance. Am J Physiol Endocrinol Metab. 2001; 280:E315-22. [PubMed: 11158936]

23. Wei CC, Meng QC, Palmer R, Hageman GR, Durand J, Bradley WE, Farrell DM, Hankes GH, Oparil S, Dell'Italia LJ. Evidence for angiotensin-converting enzyme- and chymase-mediated angiotensin II formation in the interstitial fluid space of the dog heart in vivo. Circulation. 1999; 99:2583-9. [PubMed: 10330392]

24. Gradman AH, Wilson JT. Hypertension and diastolic heart failure. Curr Cardiol Rep. 2009; 11:422-9. [PubMed: 19863866]

25. Verma A, Solomon SD. Diastolic dysfunction as a link between hypertension and heart failure. Med Clin North Am. 2009; 93:647-64. [PubMed: 19427497] 
26. Li M, Liu K, Michalicek J, Angus JA, Hunt JE, Dell'Italia LJ, Feneley MP, Graham RM, Husain A. Involvement of chymase-mediated angiotensin II generation in blood pressure regulation. J Clin Invest. 2004; 114:112-20. [PubMed: 15232618]

27. Bartelds B, van Loon RL, Mohaupt S, Wijnberg H, Dickinson MG, Boersma B, Takens J, van Albada M, Berger RM. Mast cell inhibition improves pulmonary vascular remodeling in pulmonary hypertension. Chest. 2012; 141:651-60. [PubMed: 21940767]

28. Mina Y, Rinkevich-Shop S, Konen E, Goitein O, Kushnir T, Epstein FH, Feinberg MS, Leor J, Landa-Rouben N. Mast cell inhibition attenuates myocardial damage, adverse remodeling, and dysfunction during fulminant myocarditis in the rat. J Cardiovasc Pharmacol Ther. 2013; 18:15261. [PubMed: 23172937]

29. Veerappan A, Reid AC, O'Connor N, Mora R, Brazin JA, Estephan R, Kameue T, Chen J, Felsen D, Seshan SV, Poppas DP, Maack T, Silver RB. Mast cells are required for the development of renal fibrosis in the rodent unilateral ureteral obstruction model. Am J Physiol Renal Physiol. 2012; 302:F192-204. [PubMed: 21957176]

30. de Almeida PW, Melo MB, Lima Rde F, Gavioli M, Santiago NM, Greco L, Jesus IC, Nocchi E, Parreira A, Alves MN, Mitraud L, Resende RR, Campagnole-Santos MJ, Dos Santos RA, Guatimosim S. Beneficial effects of angiotensin-(1-7) against deoxycorticosterone acetate-induced diastolic dysfunction occur independently of changes in blood pressure. Hypertension. 2015; 66:389-95. [PubMed: 26077567]

31. Chang P, Wang Q, Xu H, Yang M, Lin X, Li X, Zhang Z, Zhang X, Zhao F, Zhao X, Bai F, Yu J. Tetrahydrobiopterin reverse left ventricular hypertrophy and diastolic dysfunction through the $\mathrm{PI} 3 \mathrm{~K} / \mathrm{p}$-Akt pathway in spontaneously hypertensive rats. Biochem Biophys Res Commun. 2015; 463:1012-20. [PubMed: 26093301]

32. Liu YS, Huang ZW, Wang L, Liu XX, Wang YM, Zhang Y, Zhang M. Sitagliptin alleviated myocardial remodeling of the left ventricle and improved cardiac diastolic dysfunction in diabetic rats. J Pharmacol Sci. 2015; 127:260-74. [PubMed: 25837922]

33. Cao N, Wong YG, Rosli S, Kiriazis H, Huynh K, Qin C, Du XJ, Kemp-Harper BK, Ritchie RH. Chronic administration of the nitroxyl donor 1-nitrosocyclo hexyl acetate limits left ventricular diastolic dysfunction in a mouse model of diabetes mellitus in vivo. Circ Heart Fail. 2015; 8:57281. [PubMed: 25737497]

34. Tsai CT, Wu CK, Lee JK, Chang SN, Kuo YM, Wang YC, Lai LP, Chiang FT, Hwang JJ, Lin JL. NF-a down-regulates sarcoplasmic reticulum $\mathrm{Ca}^{2+}$ ATPase expression and leads to left ventricular diastolic dysfunction through binding of NF- $\kappa \mathrm{B}$ to promoter response element. Cardiovasc Res. 2015; 105:318-29. [PubMed: 25712896]

35. Wilson K, Guggilam A, West TA, Zhang X, Trask AJ, Cismowski MJ, de Tombe P, Sadayappan S, Lucchesi PA. Effects of a myofilament calcium sensitizer on left ventricular systolic and diastolic function in rats with volume overload heart failure. Am J Physiol Heart Circ Physiol. 2014; 307:H1605-17. [PubMed: 25260618]

36. Little WC, Oh JK. Echocardiographic evaluation of diastolic function can be used to guide clinical care. Circulation. 2009; 120:802-809. [PubMed: 19720946]

37. Nagueh SF, Appleton CP, Gillebert TC, Marino PN, Oh JK, Smiseth OA, Waggoner AD, Flachskampf FA, Pellikka PA, Evangelisa A. Recommendations for the evaluation of left ventricular diastolic function by echocardiography. Eur J Echocardiogr. 2009; 10:165-193. [PubMed: 19270053]

38. Appleton CP. Influence of incremental changes in heart rate on mitral flow velocity: assessment in lightly sedated, conscious dogs. J Am Coll Cardiol. 1991; 17:227-236. [PubMed: 1987230]

39. Stoddard MF, Pearson AC, Kern MJ, Ratcliff J, Mrosek DG, Labovitz AJ. Influence of alteration in preload on the pattern of left ventricular diastolic filling as assessed by Doppler echocardiography in humans. Circulation. 1989; 79:1226-1236. [PubMed: 2498005]

40. Ommen SR, Nishimura RA, Appleton CP, Miller FA, Oh JK, Redfield MM, Tajik AJ. Clinical utility of Doppler echocardiography and tissue Doppler imaging in the estimation of left ventricular filling pressures: A comparative simultaneous Doppler-catheterization study. Circulation. 2000; 102:1788-1794. [PubMed: 11023933] 
41. Nagueh SF, Mikati I, Kopelen HA, Middleton KJ, Quiñones MA, Zoghbi WA. Doppler estimation of left ventricular filling pressure in sinus tachycardia. A new application of tissue doppler imaging. Circulation. 1998; 98:1644-1650. [PubMed: 9778330]

42. Lee SW, Park MC, Park YB, Lee SK. E/E' ratio is more sensitive than E/A ratio for detection of left ventricular diastolic dysfunction in systemic lupus erythematosus. Lupus. 2008; 17:195-201. [PubMed: 18372359]

43. Lee SW, Choi EY, Jung SY, Choi ST, Lee SK, Park YB. E/E' ratio is more sensitive than E/A ratio for detection of left ventricular diastolic dysfunction in patients with systemic sclerosis. Clin Exp Rheumatol. 2010; 28(Suppl 58):S12-S17. [PubMed: 20576210]

44. Dubey RK, Oparil S, Imthurn B, Jackson EK. Sex hormones and hypertension. Cardiovasc Res. 2002; 53:688-708. [PubMed: 11861040]

45. Meyer MR, Haas E, Barton M. Gender differences of cardiovascular disease: new perspectives for estrogen receptor signaling. Hypertension. 2006; 47:1019-26. [PubMed: 16651458]

46. Cutler JA, Sorlie PD, Wolz M, Thom T, Fields LE, Roccella EJ. Trends in hypertension prevalence, awareness, treatment, and control rates in United States adults between 1988-1994 and 1999-2004. Hypertension. 2008; 52:818-27. [PubMed: 18852389]

47. Yanes LL, Reckelhoff JF. Postmenopausal hypertension. Am J Hypertens. 2011; 24:740-9. [PubMed: 21509049]

48. Kirimura K, Takai S, Jin D, Muramatsu M, Kishi K, Yoshikawa K, Nakabayashi M, Mino Y, Miyazaki M. Role of chymase-dependent angiotensin II formation in regulating blood pressure in spontaneously hypertensive rats. Hypertens Res. 2005; 28:457-64. [PubMed: 16156510]

49. Levick SP, Gardner JD, Holland M, Hauer-Jensen M, Janicki JS, Brower GL. Protection from adverse myocardial remodeling secondary to chronic volume overload in mast cell deficient rats. $\mathbf{J}$ Mol Cell Cardiol. 2008; 45:56-61. [PubMed: 18538342]

50. Bhattacharya K, Farwell K, Huang M, Kempuraj D, Donelan J, Papaliodis D, Vasiadi M, Theoharides TC. Mast cell deficient W/Wv mice have lower serum IL-6 and less cardiac tissue necrosis than their normal littermates following myocardial ischemia-reperfusion. Int $\mathrm{J}$ Immunopathol Pharmacol. 2007; 20:69-74. [PubMed: 17346429]

51. Hara M, Ono K, Hwang MW, Iwasaki A, Okada M, Nakatani K, Sasayama S, Matsumori A. Evidence for a role of mast cells in the evolution to congestive heart failure. J Exp Med. 2002; 195:375-81. [PubMed: 11828013]

52. Levick SP, McLarty JL, Murray DB, Freeman RM, Carver WE, Brower GL. Cardiac mast cells mediate left ventricular fibrosis in the hypertensive rat heart. Hypertension. 2009; 53:1041-7. [PubMed: 19398662]

53. Garland LG, Adcock JJ. New approaches to the attenuation of sensory reflexes in airway inflammation. Agents Actions Suppl. 1991; 34:497-517. [PubMed: 1793081]

54. Janssen LJ, Wattie J, Betti PA. Effects of cromolyn and nedocromil on ion currents in canine tracheal smooth muscle. Eur Respir J. 1998; 12:50-6. [PubMed: 9701414]

55. Lu H, Meléndez GC, Levick SP, Janicki JS. Prevention of adverse cardiac remodeling to volume overload in female rats is the result of an estrogen-altered mast cell phenotype. Am J Physiol Heart Circ Physiol. 2012; 302:H811-7. [PubMed: 22160000]

56. Izzo G, d'Istria M, Serino I, Minucci S. Inhibition of the increased 17beta-estradiol-induced mast cell number by melatonin in the testis of the frog Rana esculenta, in vivo and in vitro. J Exp Biol. 2004; 207:437-41. [PubMed: 14691091]

57. Di Matteo L, Vitiello II, Minucci S. Effects of sex steroid hormones and their antagonists on mast cell number in the testis of the frog, Rana esculenta. Zygote. 2000; 8:225-34. [PubMed: 11014502]

58. Di Matteo L, Chieffi Baccari G, Chieffi P, Minucci S. The effects of testosterone and estradiol on mast cell number in the harderian gland of the frog, Rana esculenta. Zoolog Sci. 1995; 12:457-66. [PubMed: 8528017]

59. Jing H, Wang Z, Chen Y. Effect of oestradiol on mast cell number and histamine level in the mammary glands of rat. Anat Histol Embryol. 2012; 41:170-6. [PubMed: 22112012] 
60. Lee KS, Kim SR, Park SJ, Min KH, Lee KY, Choe YH, Park SY, Chai OH, Zhang X, Song CH, Lee YC. Mast cells can mediate vascular permeability through regulation of the PI3K-HIF-1alphaVEGF axis. Am J Respir Crit Care Med. 2008; 178:787-797. [PubMed: 18669818]

61. Shaik-Dasthagirisaheb YB, Varvara G, Murmura G, Saggini A, Potalivo G, Caraffa A, Antinolfi P, Tete' S, Tripodi D, Conti F, Cianchetti E, Toniato E, Rosati M, Conti P, Speranza L, Pantalone A, Saggini R, Theoharides TC, Pandolfi F. Vascular endothelial growth factor (VEGF), mast cells and inflammation. Int J Immunopathol Pharmacol. 2013; 26:327-335. [PubMed: 23755748]

62. Solomon SD, Janardhanan R, Verma A, Bourgoun M, Daley WL, Purkayastha D, Lacourcière Y, Hippler SE, Fields H, Naqvi TZ, Mulvagh SL, Arnold JM, Thomas JD, Zile MR, Aurigemma GP. Valsartan In Diastolic Dysfunction (VALIDD) Investigators. Effect of angiotensin receptor blockade and antihypertensive drugs on diastolic function in patients with hypertension and diastolic dysfunction: a randomized trial. Lancet. 2007; 369:2079-2087. [PubMed: 17586303]

63. Solomon SD, Verma A, Desai A, Hassanein A, Izzo J, Oparil S, Lacourciere Y, Lee J, Seifu Y, Hilkert RJ, Rocha R, Pitt B. Exforge Intensive Control of Hypertension to Evaluate Efficacy in Diastolic Dysfunction Investigators. Effect of intensive versus standard blood pressure lowering on diastolic function in patients with uncontrolled hypertension and diastolic dysfunction. Hypertension. 2010; 55:241-248. [PubMed: 19996069]

64. Theoharides TC, Alysandratos KD, Angelidou A, Delivanis DA, Sismanopoulos N, Zhang B, Asadi S, Vasiadi M, Weng Z, Miniati A, Kalogeromitros D. Mast cells and inflammation. Biochim Biophys Acta. 2012; 1822:21-33. [PubMed: 21185371] 


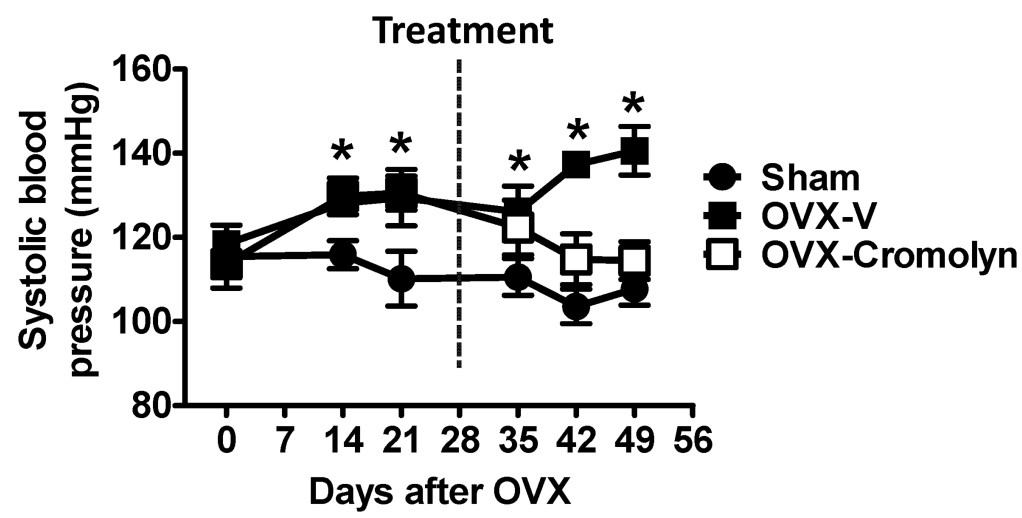

Figure 1.

Tail-cuff systolic blood pressure in conscious, sham-operated and ovariectomized (OVX) female Fischer $344 \times$ Brown Norway $(F 344 B N)$ rats treated with vehicle (V) or cromolyn for 4 weeks. Values are means $\pm \mathrm{SEM} ; * P<0.05$ vs. sham. $\mathrm{n}=7$ /group. 

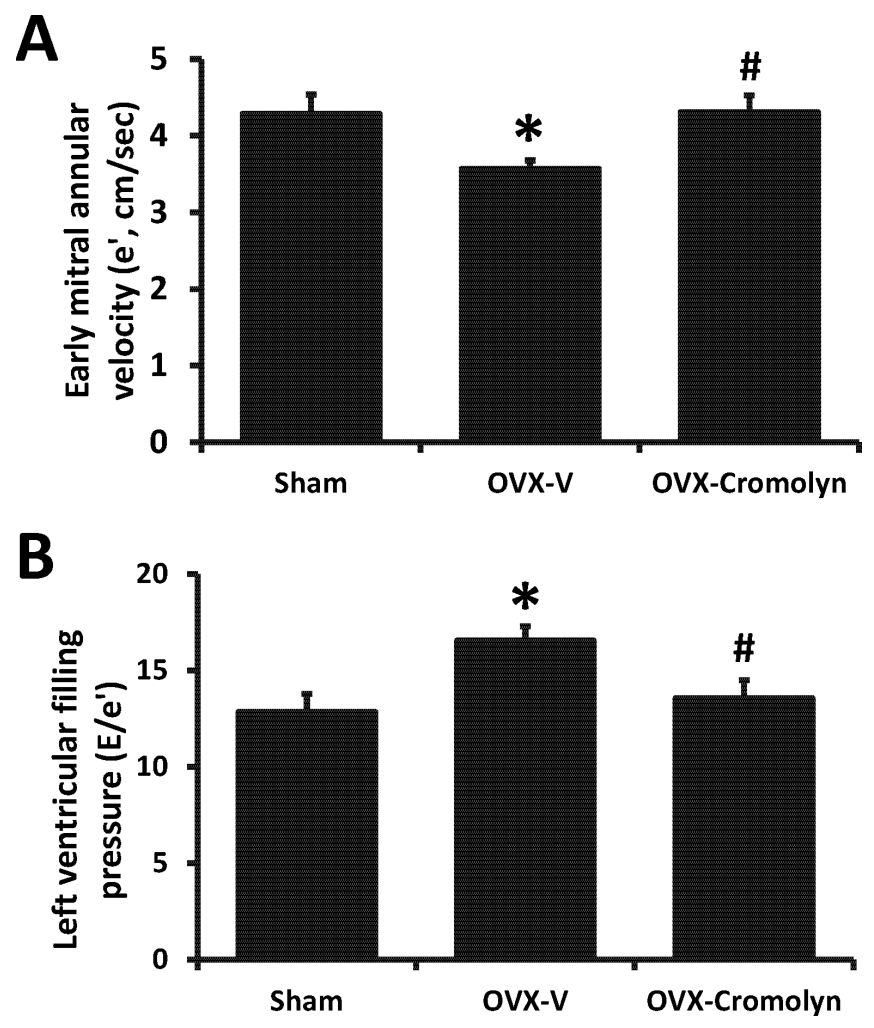

Figure 2.

Echocardiographic measurements in sham-operated and ovariectomized (OVX) female Fischer 344×Brown Norway (F344BN) rats treated with vehicle (V) or cromolyn for 4 weeks. A) Myocardial relaxation indicated by early mitral annular velocity ( $\left.\mathrm{e}^{\prime}\right)$, and B) Ratio of early transmitral filling velocity to mitral annular velocity $\left(E / e^{\prime}\right)$. Values are means \pm $\mathrm{SEM} ; * P<0.05$ vs. sham; $\# P<0.05$ vs. OVX-V. $\mathrm{n}=7 /$ group. 

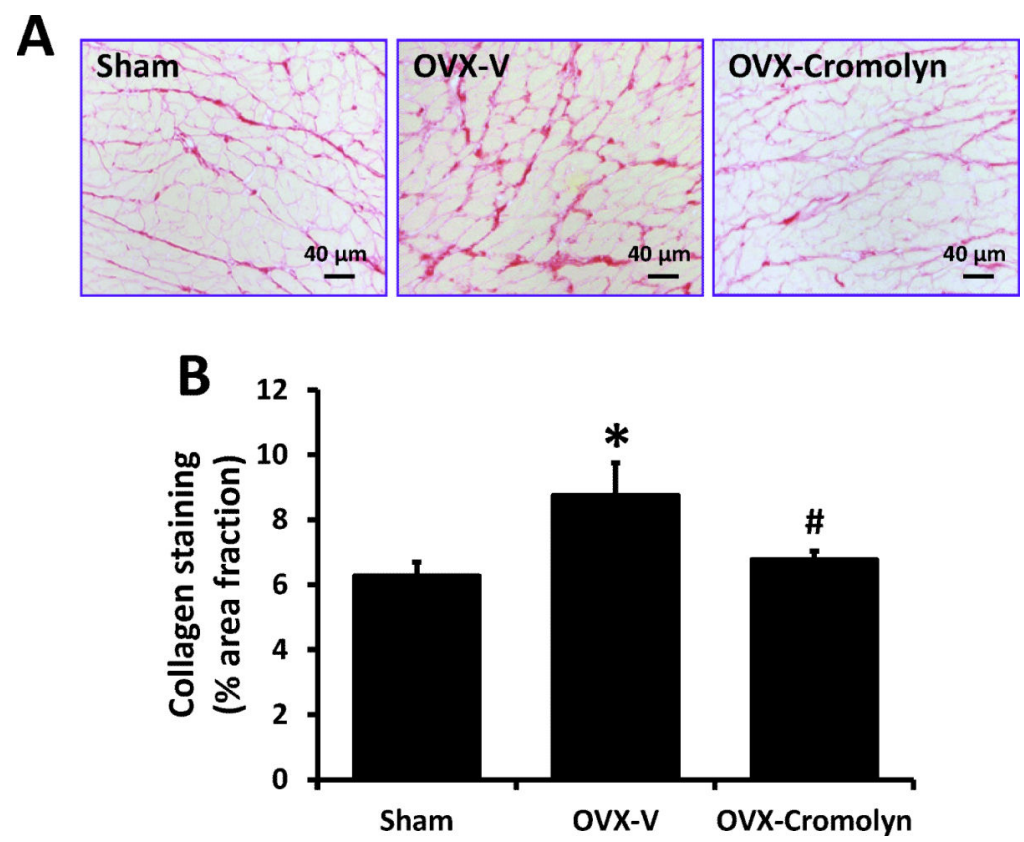

Figure 0003
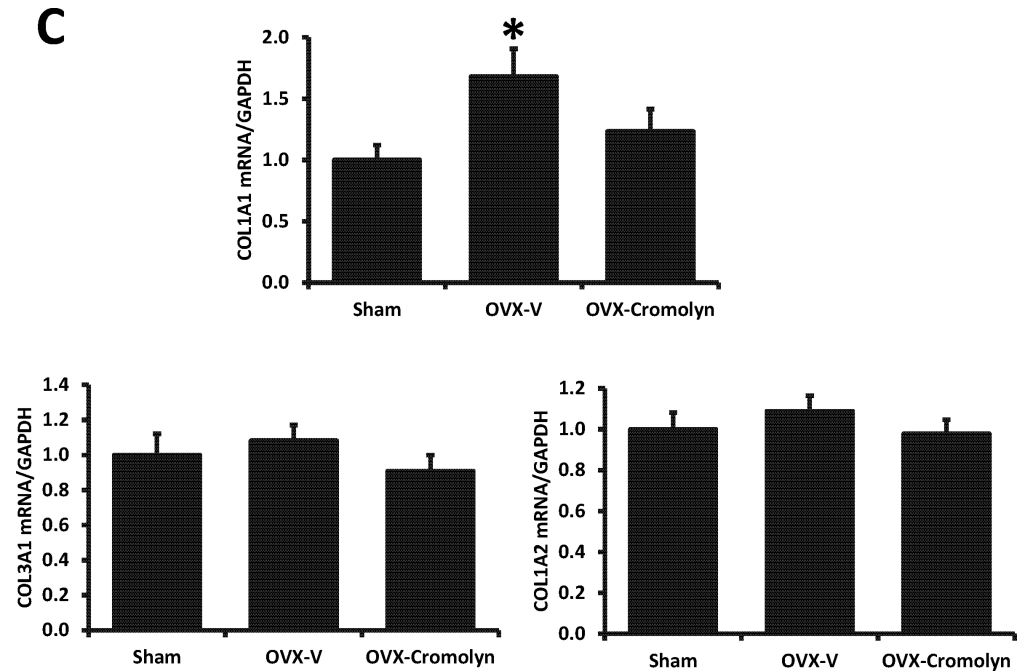

Figure 0004

Figure 3.

Interstitial fibrosis in sham-operated and ovariectomized (OVX) female Fischer $344 \times$ Brown Norway (F344BN) rats treated with vehicle (V) or cromolyn for 4 weeks. A) Representative LV images of collagen deposition determined by picrosirius red staining in each group ( $\times 200$ magnification); B) Quantification of collagen deposition using ImageJ software; C) Collagen mRNA levels in LVs determined by real-time qPCR. COL1A1, collagen type I alpha 1; COL1A2, collagen type I alpha 2; COL3A1, collagen type III alpha 1. Values are means $\pm \mathrm{SEM} ; * P<0.05$ vs. sham; $\# P<0.05$ vs. OVX-V. $\mathrm{n}=7 /$ group. 

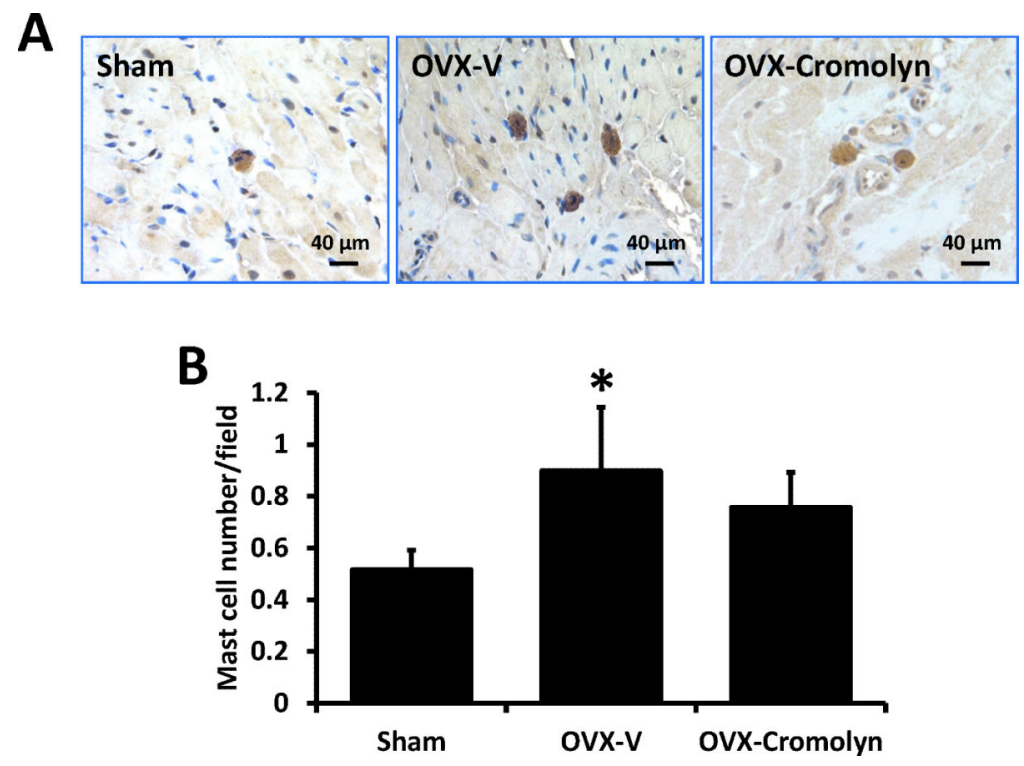

Figure 4.

Mast cell numbers in the left ventricles of sham-operated and ovariectomized (OVX) female Fischer 344×Brown Norway (F344BN) rats treated with vehicle (V) or cromolyn for 4 weeks. A) Representative images showing mast cell staining with anti-chymase antibody. B) Quantification of cardiac mast cell number. Values are means \pm SEM; $* P<0.05$ vs. sham. $\mathrm{n}=7$ /group. 
A

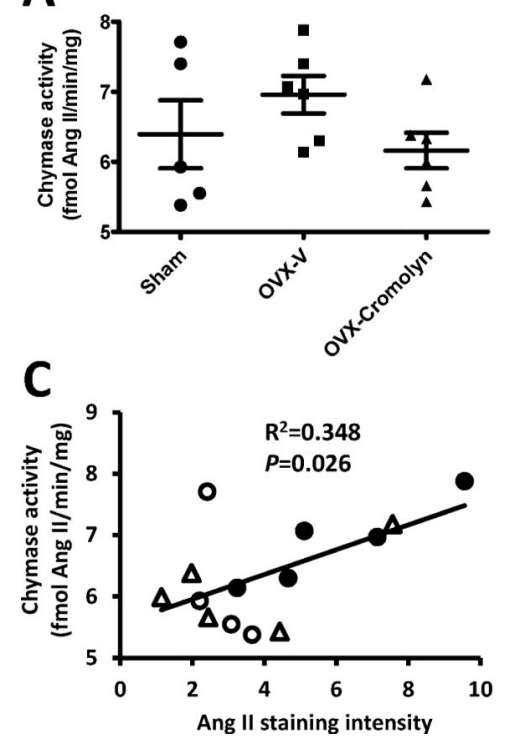

B
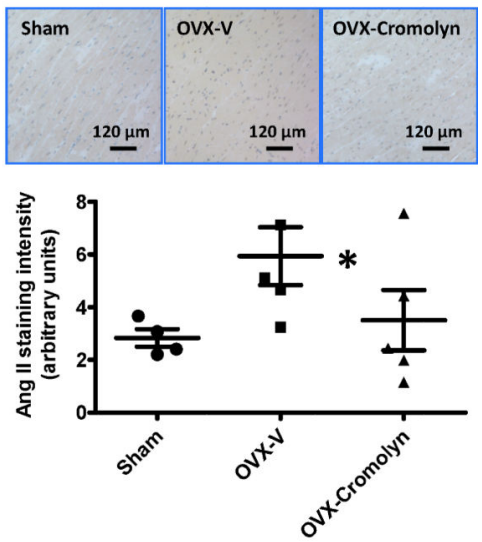

Figure 5.

Cardiac chymase activity and angiotensin II (Ang II) content in the left ventricles of shamoperated and ovariectomized (OVX) female Fischer 344×Brown Norway (F344BN) rats treated with vehicle (V) or cromolyn for 4 weeks. A) Chymase activity in left ventricles; B) Representative images showing immunohistochemical staining for Ang II in the left ventricles (upper panel), and Ang II staining intensity quantification using ImageJ (lower panel); C) Correlation analysis of cardiac Ang II staining intensity with cardiac chymase activity. $\bigcirc$ : sham, O: OVX-V, $\Delta$ : OVX-cromolyn. Values are means $\pm \mathrm{SEM} ;{ }^{*} P<0.05$ vs. sham. $n=5$-6/group. 


\section{Table 1}

Echocardiographic Indices of Cardiac Structure and Functions

\begin{tabular}{lccc}
\hline & Sham & OVX-V & OVX-Cromolyn \\
\hline Body weight $(\mathrm{g})$ & $274 \pm 9$ & $293 \pm 7^{*}$ & $267 \pm 10$ \\
Left ventricle/tibial length $(\mathrm{mg} / \mathrm{mm})$ & $12.3 \pm 0.5$ & $12.4 \pm 0.3$ & $12.4 \pm 0.5$ \\
Heart rate (bpm) & $283 \pm 10$ & $275 \pm 9$ & $288 \pm 19$ \\
Left ventricle mass & $0.624 \pm 0.05$ & $0.818 \pm 0.07^{*}$ & $0.721 \pm 0.03$ \\
Relative wall thickness & $0.49 \pm 0.04$ & $0.68 \pm 0.05$ & $0.56 \pm 0.02$ \\
Left ventricular end systolic dimension $(\mathrm{cm})$ & $0.26 \pm 0.02$ & $0.31 \pm 0.01$ & $0.32 \pm 0.02$ \\
Left ventricular end diastolic dimension $(\mathrm{cm})$ & $0.59 \pm 0.04$ & $0.62 \pm 0.01$ & $0.63 \pm 0.01$ \\
Fractional shortening (\%) & $56.1 \pm 2.1$ & $51.6 \pm 2.6$ & $48.7 \pm 2.3$ \\
E-wave deceleration time time (s) & $0.046 \pm 0.003$ & $0.048 \pm 0.002$ & $0.052 \pm 0.003$ \\
Emax (cm/s) & $52.9 \pm 3.5$ & $58.3 \pm 1.7$ & $56.6 \pm 2.5$ \\
Amax (cm/s) & $37.0 \pm 2.2$ & $41.2 \pm 2.9$ & $39.8 \pm 2.4$ \\
E/A & $1.44 \pm 0.07$ & $1.46 \pm 0.14$ & $1.46 \pm 0.11$ \\
Myocardial performance index & $0.22 \pm 0.02$ & $0.33 \pm 0.03$ & $0.29 \pm 0.02$ \\
\hline
\end{tabular}

$V$ vehicle; $O V X$ ovariectomized; Emax maximum early transmittal filling velocity; Amax maximum late transmitral filling velocity; $E / A$ early-tolate transmitral filling ratio; MPI myocardial performance index. Data are expressed as mean $\pm \mathrm{SEM}$.

${ }^{*} P<0.05$ vs. Sham. 